\title{
THE CANADIAN CONSTITUTIONAL AMENDMENT PROCESS
}

\author{
STEPHEN A. SCOTT*
}

\section{Prologue}

No one, as recently as two years ago, could have foreseen, even in general outline, the nature of the major Canadian constitutional reform now but ten days old. One cannot but marvel at the hazards and vicissitudes which attend constitutionmaking. Indeed, I note, with much relief, that, on August 20, 1787, the American Constitutional Convention at Philadelphia, by a vote of eight states to three, defeated a proposal to empower the "[l]egislature of the United States" to "make sumptuary laws." I count it my great good fortune that Congress cannot restrain the otherwise limitless bounds of your hospitality. Mr. Mason of Virginia, indeed, denounced as "a vulgar error" the objection that sumptuary laws "were contrary to nature;" whilst Mr. Elseworth [sic] of Connecticut presciently replied that " $t \mathrm{t}$ ] best remedy is to enforce taxes and debts. As far as the regulation of eating \& drinking can be reasonable, it is provided for in the power of taxation."2 Governeur [sic] Morris of Pennsylvania warned that "sump. laws were calculated to continue great landed estates for ever in the same families-If men had no temptation to dispose of their money they would not sell their estates." 3 North Carolina, I am pleased to note, was amongst the states opposed to federal sumptuary laws.

While it would be churlish even to hint at liquidation of your endowments in the interests of conviviality, I am sure that, as Mr. Ellsworth would doubtless have done, we will all see in President Reagan's tax reductions the direction of American public policy, and, as good citizens, be moved accordingly.

\section{I}

\section{INTRODUCTION}

On April 17, 1982, Canada became, in terms of its own internal law, a sovereign state legally independent of the United Kingdom. ${ }^{4}$ Legal reality was brought

* Of the Bar of the Province of Quebec and the Faculty of Law, McGill University. (The author, critical of inaccuracies in the American style of citation, has requested specific identification of United Kingdom statutes and statutes of Great Britain. Other deviations from American style are likewise used at the author's request.)

1. 2 Records of the Federal Convention of 1787, at 337, 344 (M. Farrand 2d ed. 1937).

2. Id. at 344 .

3. Id. at 351 .

4. Canada Act 1982,1982 ch. 11 (U.K.), $\$ \S 1$ and 2. By its terms, section 2 operates from the coming into force of the Constitution Act, 1982 (which itself is Schedule B to the Canada Act 1982). Pursuant to section 58 thereof, the Constitution Act 1982 was (subject to section 59) brought into force by proclamation of Her Majesty the Queen at Ottawa in a mid-morning ceremony on that date. See infra note 21 
into accord with an internationally-recognized political reality of at least fifty years' standing. The intervening decades had been marked by repeated, and unsuccessful, attempts ${ }^{5}$ within Canada to devise legal processes to which the residual sovereignty of the United Kingdom Parliament might be transferred: in other words, to define a new sovereign or constituent authority for Canada.

Rehearsal of the history of these attempts-even a very summary rehearsalwould carry us much too far afield. Suffice it to begin at a rather recent date, and to recall that, on October 2, 1980, the Government of Canada presented to the House of Commons of Canada a draft constitutional text ${ }^{6}$ having more or less the scope of (though very different provisions from) the reform which recently became law. The October 1980 text was proposed as the terms of a joint address by both Houses of the federal parliament to the Sovereign, praying for the enactment by the United Kingdom Parliament of a statute which would confer upon Canada legal independence with a series of constitutional amending processes and a Canadian Charter of Rights and Freedoms "entrenched" against both the federal parliament and the provincial legislatures. It was intended to proceed to Westminster without the consent of the provincial legislatures or governments.

This scheme immediately encountered opposition and resistance-in most cases, opposition and resistance of the most sustained and bitter character-from the opposition parties (the Progressive Conservatives especially) in the federal parliament, and from eight of the ten provincial governments: all, that is, save Ontario and New Brunswick.

A special Joint Committee of the Senate and the House of Commons of Canada was appointed to consider the draft. Its report, ${ }^{7}$ tabled in the House of Commons on February 13, 1981, proposed a variety of changes. Although various compromises had succeeded in securing the (rather unenthusiastic) concurrence of the federal New Democratic Party, and of most of its M.P.'s, the revised draft was met with nearly the same obstruction in the House as its predecessor, and no less opposition from the provinces. Only on April 8, 1981-with no end to the debate in sight-was all-party agreement on procedure announced in the House of Commons. ${ }^{8}$ Under this agreement a special order was unanimously adopted, fixing a timetable for the disposition of all amendments to the text reported from the Committee, and, ultimately, for the disposition of the final text as it might be amended. This agreement, however, committed the government to await the judgment of the Supreme Court of Canada on pending appeals from decisions of the Manitoba, the Newfoundland, and the Quebec Courts of Appeal on questions referred to them by the governments of these provinces, both as to the constitutional propriety and the

5. See, e.g., the accounts in P. GÉRIN-Lajoie, ConstituUtional Amendment in Canada (1950), and Editor's Diary, introducing a symposium in 12 MCGiLL L.J. 337 (1966-67).

6. Aoposed Resolution for a Joint Address to Her Majesty the Queen respecting the Constitution of Canada (October 2, 1980), Government of Canada, document number 25005-2-10-80.

7. Canada, House of Commons, Votes and Proceedings, Friday, February 13, 1981, being 32nd Parliament, 1st Session, No. 142, at $1244 \mathrm{ff}$.

8. Canada, House of Commons, Votes and Proceedings, Wednesday, April 8, 1981, being 32nd Parliament, 1st Session, No. 179, at 1677 ff. See also 8 House of Commons Debates 9072 ff. (Apr. 8 , 1981). 
legal validity or consequences of the course of action upon which the federal Houses had embarked.

The Supreme Court of Canada's majority decision of September 28, 1981,9 held that, as a matter of law, the authority of the United Kingdom Parliament survived intact and unimpaired; that is, it could validly and effectively legislate on the Canadian constitution, either on its own motion or in response to any request of its choosing. But the Court also held that (extra-legal) "conventions" existed rendering constitutionally improper a federal parliamentary approach to the Imperial Parliament without a sufficient provincial consensus; and that, whatever the "necessary" consensus might be, the two provinces of Ontario and New Brunswick did not suffice. ${ }^{10}$

Even if it had remained politically possible for federal parliamentary majorities to force the measure as it then stood (with amendments approved by the House of Commons on April 23, 1981, ${ }^{11}$ and by the Senate on April 24, 1981 ${ }^{12}$ ) through both Houses of the Canadian Parliament, it was doubtful that the Government of the United Kingdom would (even, perhaps, that it could) carry a bill in the terms requested through the Parliament at Westminster.

A negotiated solution became the only alternative. This was achieved on November 5, 1981,13 the signatories being the governments of Canada and of all provinces save Quebec. The agreed scheme was based largely on an earlier interprovincial agreement of April 16,1981 (the "April Accord") amongst the eight "opposing" provincial governments. In particular, the federal-provincial agreement of November 5, 1981, introduced the "legislative override" (reflected in section 33 of the Constitution Act, 1982) ${ }^{14}$ allowing the Parliament of Canada and the provincial legislatures to override, by express statutory language, most of the guarantees of the Canadian Charter of Rights and Freedoms. It also adopted from the "April Accord" a scheme of constitutional amending formulae which Prime Minister Trudeau had repeatedly denounced as tending to create a "chequerboard Canada." These amending procedures had, and have, almost no resemblance on essential points to the federal proposals which they displaced.

The Minister of Justice of Canada, by notice of motion of November 18, 1981,

9. Reference re Amendment of the Constitution of Canada (Nos. 1, 2 \& 3) 125 D.L.R.3d 1, 41 (Can. $1981)$.

10. Id. at 103 .

11. Canada, House of Commons, Votes AND Proceedinas, Thursday, April 23, 1981, being 32nd Parliament, 1st Session, No. 187, at $1741 \mathrm{ff}$.

12. Canada, Minutes of Proceedings of the Senate, Friday, April 24, 1981, being 32nd Parliament, 1st Session, No. 117, at $1150 \mathrm{ff}$. The proposals, as they then stood, are most conveniently read in a consolidation printed by the Department of Justice of Canada, TEXT OF PROPOSED CONSTITUTIONAL Resolution filed by the Deputy attorney General of Canada with the Supreme Court of CANADA ON APRIL 24, 1981 , document number 25005-24-4-81.

13. The (unpublished) document recording the agreement was tabled by the Prime Minister in the House of Commons on November 5, 1981; see House OF COMMONS DEBATES for that date, at $12536 \mathrm{ff}$., and in particular the Prime Minister's statement.

14. The Constitution Act, 1982, is Schedule B of the Canada Act 1982, $1982 \mathrm{ch} .11$, the United Kingdom statute enacted on March 29, 1982, to give effect to the request of the Senate and House of Commons of Canada that the provisions of the Constitution Act, 1982, be enacted. See text accompanying notes 21-28 infra. 
accordingly introduced into the House of Commons a resolution ${ }^{15}$ for a joint address to the Sovereign conforming to the federal-provincial agreement. Although changes had been made in order to accommodate positions adopted by the Government of Quebec, it proved impossible to secure the province's agreement to the project. Quebec has remained steadfastly and intransigently opposed to the ultimate Canada Act and has not accepted the issue as settled politically.

On December 2, 1981, the House of Commons of Canada, ${ }^{16}$ and, on December 8,1981 , the Senate of Canada ${ }^{17}$ adopted the final text of what has now become the Canada Act, 1982 - the ultimate exercise of Imperial legislative authority for Canada.

\section{II}

\section{"PATRIATION"}

[T] he King's Majesty, by and with the Advice and Consent of the Lords Spiritual and Temporal, and Commons of Great Britain . . . had, hath, and of Right ought to have, full Power and Authority to make Laws . . of sufficient Force and Validity to bind the Colonies and People of America, Subjects of the Crown of Great Britain, in all Cases whatsoever. ${ }^{18}$

He has combined with others to subject us to a jurisdiction foreign to our constitution, and unacknowledged by our laws, giving his Assent to their acts of pretended Legislation: ... . For . . declaring themselves invested with Power to legislate for us in all cases whatsoever. ${ }^{19}$

The British Parliament's statutory challenge in the "Declaratory Act" of 1766 drew from the inhabitants of the North American "thirteen colonies" their formal response in the Declaration of Independence ten years later. For them, Imperial legislative supremacy was ended by war: its end was consecrated by treaty ${ }^{20}$ in 1783.

On April 17, 1982, Her Majesty Queen Elizabeth II, in a mid-morning ceremony at Ottawa, proclaimed ${ }^{21}$ into force the Canada Act $1982^{22}$ (with its sched-

15. The text, standing in the name of the Minister of Justice and dated November 18, 1981, may be found under "Government Notices of Motions" at xiv $\mathrm{ff}$. of the "Notice Paper" appended to Canadian House of Commons Order Paper and Notices, Thursday, November 19, 1981, being 32nd Parliament, 1st Session, No. 259.

16. Canada, House of Commons, Votes and Proceedings, Wednesday, December 2, 1981, being 32nd Parliament, 1st Session, No. 268, at $4304 \mathrm{ff}$. The final text, incorporating amendments, appears at $4308 \mathrm{ff}$., and is separately printed under the title TEXT OF THE RESOLUTION RESPECTINC THE CONSTITUtion of Canada aDOPTED by the House of Commons on December 2, 1981, document number 25005-2-12-81.

17. Canada, Minutes of Proceedings of the Senate, Tuesday, December 8, 1981, being 32nd Parliament, 1st Session, No. 162, at $1722 \mathrm{ff}$. The final text, incorporating amendments, and approved on division, appears at $1759 \mathrm{ff}$.

18. An Act for the better securing the Dependency of Her Majesty's Dominions in America upon the Crown and Parliament of Great Britain (American Colonies Act), 1766, 6 Geo. 3, ch. 12 (G.B.).

The American Colonies Act of 1766 long survived the particular historical circumstances which had induced its passage, standing on the British statute book until its repeal by the Statute Law Revision Act, 1964, 1964 ch. 79 (U.K.), which collectively declared a number of acts to be "obsolete, spent or unnecessary or . . . superseded by other enactments." Id. at $\S 1$.

19. The Declaration of Independence, paras. 15, 24 (U.S. 1776).

20. Treaty of Versailles, Jan. 20, 1783, 8 Stat. 58, T.I.A.S. No. 103, at 6.

21. Can. Gaz. Extra No. 20 (April 17, 1982), 116 Can. Gaz. Part I 2927-28 (1982); see also Canada Act 1982, 1982 ch. 11 (U.K.). 
uled Constitution Act, 1982), to which Her Majesty had assented in the United Kingdom Parliament on March 29, 1982. With effect from the beginning of the day of Proclamation, ${ }^{23}$ the overriding legislative sovereignty of the United Kingdom Parliament-declared for the Empire generally in the Colonial Laws Validity Act, $1865,{ }^{24}$ and effectually preserved for Canada by section 7 of the Statute of Westminster, $1931^{25}$ - came to an end for us. The Canada Act 1982,,6 with its Schedule B, the Constitution Act, 1982,27 substituted for the "Imperial" legislative authority of the United Kingdom Parliament (and for certain existing "domestic" constitutional amendment processes ${ }^{28}$ of rather limited scope) the procedures which this paper will examine. These procedures are found in Part $\mathrm{V}$ of the Constitution Act, 1982, entitled "Procedure for Amending Constitution of Canada."

22. Id.

23. Interpretation Act, 1889, 52 \& 53 Vict., ch. 63 (U.K.), § 36(2); see also Regina v. Logan, [1957] 2 Q.B. 589, 590-91.

As to the operation of section 58 of the Constitution Act, 1982, providing that for most purposes the Act would come into force on a day to be fixed by proclamation of the Queen or the Governor General under the Great Seal of Canada, see Interpretation Act, 1889, 52 \& 53 Vict., ch. 63 (U.K.), 337.

24. 28 \& 29 Vict., ch. 63 (U.K.). Section 2 of the Act provides:

Any Colonial Law which is or shall be in any respect repugnant to the Provisions of any Act of

Parliament extending to the Colony to which such Law may relate, or repugnant to any Order or Regulation made under the Authority of such Act of Parliament, or having in the Colony the Force and Effect of such Act, shall be read subject to such Act, Order, or Regulation, and shall, to the extent of such Repugnancy, but not otherwise, be and remain absolutely void and inoperative.

Section 1 provides, "An Act of Parliament, or any Provision thereof, shall, in construing this Act, be said to extend to any Colony when it is made applicable to such Colony by the express Words or necessary Intendment of any Act of Parliament ...."

25. 22 Geo. 5 , ch. 4 (U.K.). Sections 2 and $7(3)$ of the Statute empowered the Parliament of Canada, within the scope of its legislative authority, to enact laws repugnant to Imperial legislation extending to Canada. (Sections 7(2) and 7(3) of the Statute placed the provincial legislatures in the same position.)

Conversely, section 4 of the same Statute barred extension "to a Dominion" (defined by section 1 to include Canada) of any future United Kingdom statute "unless it is expressly declared in that Act that that Dominion has requested, and consented to, the enactment thereof."

The whole Statute, however, was subject to section $7(1)$, which provided that "[n]othing in this Act shall be deemed to apply to the repeal, amendment or alteration of the British North America Acts, 1867 to 1930 , or any order, rule or regulation made thereunder." This clause effectively saved an unrestricted power to exercise lawmaking authority in Canada. It left Canadian constituent power in the hands of the United Kingdom Parliament. See generally Reference re Amendment of the Constitution of Canada (Nos. 1, 2 \& 3), 125 D.L.R. 3d 1 (Can. 1981); Scott, Opinion Submitted to the Foreign Affairs Committee of the House of Commons of the United Kingdom on the Role of the United Kingdom Parliament in Relation to the [BNA] Acts, reprinted in 26 MCGiLL L.J. 614, 615-18 (1981).

26. 1982 , ch. 11 (U.K.), $\S \S 1-2$.

27. $\$ \S 52,53(1)$ and Schedule Items $1,17,22$. Together, these provisions repeal sections 4 and $7(1)$ of the Statute of Westminster, 1931, 22 Geo. 5, ch. 4 (U.K.) (see supra note 25), as well as sections 91.1 and 92.1 of the British North America Act, 1867, 30 \& 31 Vict., ch. 3 (U.K.), as amended by the British North America (No. 2) Act, 1949, 12, $13 \& 14$ Geo. 6, ch. 81 (U.K.). (The Schedule to the Constitution Act, 1982, also renames the British North America Act, 1867, as amended by the 1982 Act's Schedule, Item 1, the "Constitution Act, 1867." Hereinafter, the original name will be used unless the 1867 Act is being alluded to in its current form.)

28. British North America (No. 2) Act, 1949, 12, 13 \& 14 Geo. 6, ch. 81 (U.K.) (amending $\$ \$ 91.1$ and 92.1 of the British North America Act, 1867, 30 \& 31 Vict., ch. 3 (U.K.)). 
III

\section{"The Constitution of CANAdA" And "The Constitution of the Province"}

Anglo-Canadian public law is deeply legitimist, placing a great weight on strict legal continuity. Law may be made according to law, and not otherwise: that is, by the persons, and according to the processes, prescribed by law. Failure to comply with conditions of manner and form of lawmaking, if these be not merely directory, results in the radical nullity of the purported enactment. This approach probably results from the notion that lawmaking power-indeed public authority generally-is to be derived from the law itself, rather than from the people. The Constitution Act, 1982, represents no departure from this legitimist tradition.

Part V of the Constitution Act, 1982, is entitled "Procedure for Amending Constitution of Canada." Section 52(3) of the Constitution Act, 1982 (not found in Part V at all, but rather in "Part VII General"), imposes a condition upon the validity of amendments by providing that "[a]mendments to the Constitution of Canada shall be made only in accordance with the authority contained in the Constitution of Canada." This, in a sense, is a corollary of section 52(1), which provides that " $[\mathrm{t}]$ he Constitution of Canada is the supreme law of Canada, and any law that is inconsistent with the provisions of the Constitution is, to the extent of the inconsistency, of no force or effect."

The terms "Constitution of Canada" and "constitution of the province" appear in the various formulae of Part $V$. If a proposed enactment would amend the one or the other "constitution," section 52(3) requires that its passage must be accomplished in virtue of "the Constitution of Canada." While this is, of course, true of the making of all laws, it is clear from the language of section 52(3) and Part $\mathrm{V}$ that, in most if not all cases, recourse to the procedures of Part $\mathrm{V}$ is necessary where an amendment to either "the Constitution of Canada" or "the constitution of the province" is involved.

Thus, definition of these two classes of amendment is pertinent to the identification of the subject-matter to which the various procedures of Part $\mathrm{V}$ are addressed, and therefore to the identification of the cases where a given procedure must be employed.

At the same time, the term "Constitution of Canada" is broader than merely "Part V of the Constitution Act, 1982." Section 52(3) leaves open the possibility that pre-existing rules of law admittedly forming part of the "Constitution of Canada" may be altered by processes outside the confines of Part V; and this is so, even though that Part gives the general appearance of an exhaustive scheme. ${ }^{29}$

29. For example, it may be that despite the provisions of sections $42(1)(e)$ and 43 of the Constitution Act, 1982, section 3 of the Constitution Act, 1871, retains at least a limited operation:

The Parliament of Canada may from time to time, with the consent of the Legislature of any Province of the said Dominion, increase, diminish, or otherwise alter the limits of such Province, upon such terms and conditions as may be agreed to by the said Legislature, and may, with the like consent, make provision respecting the effect and operation of any such increase or diminution or alteration of territory in relation to any Province affected thereby. 
What, then, is "the Constitution of Canada"? Section 52(2) (with which, for the sake of convenience, is reproduced section 53(1)) gives only partial guidance:

(2) The Constitution of Canada includes

(a) the Canada Act, 1982, including this Act;

(b) the Acts and orders referred to in the schedule; and

(c) any amendment to any Act or order referred to in paragraph (a) or (b).

53. (1) The enactments referred to in Column I of the schedule are hereby repealed or amended to the extent indicated in Column II thereof and, unless repealed, shall continue as law in Canada under the names set out in Column III thereof.

Section 52(2) gives only partial guidance because, by employing the term "includes" in preference to the word "means," the definition does not purport to be exhaustive.

The list in the schedule to the Constitution Act, 1982, begins with The British North America Act, 1867, and continues with various direct and other amendments made by federal ${ }^{30}$ and Imperial statutes. The Statute of Westminster, 1931, appears in the list, as do the Imperial Orders-in-Council and federal statutes creating new provinces. Many statutory enactments not enumerated in the schedule, and many common-law rules, ${ }^{31}$ are, however, inherently quite as "constitutional" in nature as those instruments which are so enumerated.

For example, much of the "organic" law dealing with the constitution and structure of the federal parliament is to be found on the federal statute book. ${ }^{32}$ Are these enactments parts of the "Constitution of Canada"? Consider, for instance, the existing rules making a seat in any house of a provincial legislature incompatible with a seat in the House of Commons. Putting aside provincial statutory provisions, few lawyers could, from memory, venture to say with confidence where these rules are to be found, just as few could indicate the source of the rule making a seat in the Senate of Canada incompatible with a seat in the House of Commons. The answer, of course, is that the former are to be found in the House of Commons Act, ${ }^{33}$ whilst the latter is in the Act of 1867.34 They seem equally "constitutional" in their nature; and, since 1949, they would seem to have stood on an equal footing as regards Parliament's power to amend them unilaterally. ${ }^{35}$ Yet

Constitution Act, 1871, 34 \& 35 Vict., ch. 28 (U.K.), $\$ 3$ (originally the British North America Act, 1871; renamed in Item 5 of the Schedule to the Constitution Act, 1982).

Section 42(1)(e) provides that an amendment to the Constitution of Canada extending existing provinces to the territories must be made in accordance with the "general procedure" of section 38 (1). See infra Part V.

Section 43 furnishes a "special arrangements" procedure whereby certain amendments pertaining to one or more, but not all, provinces may be made. See also infra Part VII.

30. In virtue of section 91.1 of the Constitution Act, 1867, as amended (see supra note 27), and the Constitution Act, 1871, as amended (see supra note 29).

31. In Reference re Amendment of the Constitution of Canada Act (Nos. 1, 2 \& 3), 125 D.L.R.3d 1 (Can. 1981), the majority held that "part of the Constitution of Canada consists of the rules of the common law." Id. at 81. Examples follow in their Lordships' reasons. Id. at 82.

32. See, e.g., House of Commons Act, CaN. Rev. STat., ch. H-9 (1970); Senate and House of Commons Act, Can. Rev. Stat., ch. S-8 (1970); Speaker of the House of Commons Act, Can. Rev. Stat., ch. S-13 (1970); Speaker of the Senate Act, Can. Rev. STAT., ch. S-14 (1970).

33. Can. Rev. Stat., ch. H-9, \$\$ 2-5 (1970).

34. British North America Act, 1867, 30 \& 31 Vict., ch. 3 (U.K.), § 39.

35. See British North America (No. 2) Act, 1949, 12, 13 \& 14 Geo. 6, ch. 81 (U.K.), \$§ 1-2; Constitution Act, 1982, 1982 ch. 11 (U.K.), Sch. B $\S 44$. 
the relevant provisions of the House of Commons Act long antedate Parliament's acquisition in 1949 of nominate powers to amend parts of the "Constitution of Canada."36 It was doubtless (and, in my view, quite correctly) assumed that Parliament, from the birth of the federation in 1867, had legislative authority to enact such provisions, and this probably in virtue of its "residuary" authority (although section 41 of the $1867 \mathrm{Act}^{37}$ may confer a relevant power). Indeed, in upholding the constitutional validity of the federal Official Languages Act, ${ }^{38}$ Chief Justice Laskin, speaking for the Supreme Court of Canada, held as follows in Jones $v$. Attomey-General of Canada:

Apart from the effect of s. 133 and s. 91(1), to be considered later in these reasons, I am in no doubt that it was open to the Parliament of Canada to enact the Official Languages Act (limited as it is to the purposes of the Parliament and Government of Canada and to the institutions of that Parliament and Government) as being a law "for the peace, order and good Government of Canada in relation to [a matter] not coming within the Classes of Subjects . . . assigned exclusively to the Legislatures of the Provinces". The quoted words are in the opening paragraph of s. 91 of the British North America Act, 1867; and, in relying on them as constitutional support for the Official Languages Act, I do so on the basis of the purely residuary character of the legislative power thereby conferred. No authority need be cited for the exclusive power of the Parliament of Canada to legislate in relation to the operation and administration of the institutions and agencies of the Parliament and Government of Canada. Those institutions and agencies are clearly beyond provincial reach. ${ }^{39}$

Now, under section 52(2) of the Constitution Act, 1982, the rule making a seat in the Senate incompatible with a seat in the House of Commons is part of the "Constitution of Canada" since it is found in the Act of 1867, one of the enactments enumerated in the schedule. By contrast, the status of the federal statutory incompatibility of membership in a provincial legislative body with membership in the Commons of Canada cannot be determined with the same certainty.

Probably, in this particular instance, it does not much matter. For, if the relevant provisions of the House of Commons Act do form part of the "Constitution of Canada," they can be altered by simple federal statute in virtue of section 44 of the Constitution Act, 1982, and, possibly, also in virtue of the "residuary power" of Parliament. If they do not form part of the "Constitution of Canada," the federal "residuary" legislative power seems certainly available.

However, a decision that a proposed enactment would, or would not, if it became law, amend "the Constitution of Canada" (or "the constitution of the province") would, in some cases, have important consequences. Some rules of law dealing with the executive government, or the legislative institutions, of Canada or of a province may concern (for example) "the office of the Queen, the Governor General and the Lieutenant Governor of a province." If they form part of the "Constitution of Canada," these will, under section 41(a), be amendable only through a proclamation issued by the Governor General of Canada with the authorization of resolutions of the Senate and House of Commons (or of the Com-

36. See British North America (No. 2) Act, 1949, 12, 13 \& 14 Geo. 6, ch. 81 (U.K.) (adding a sweeping new section 91.1 to the 1867 Act).

37. See Constitution Act, 1867, 30 \& 31 Vict., ch. 3 (U.K.), $\$ 41$.

38. Can. Rev. Stat., ch. O-2 (1970).

39. Jones v. Attorney-Gen. of Canada, 45 D.L.R.3d 583, 588-89 (Can. 1981). 
mons alone under section 47(1)) and of the legislative assembly of every province. The common law, "received English" statute law, and "Imperial" statute law on the succession to the Crown afford a good illustrative example. If they are part of the "Constitution of Canada," section 41(a) appears to apply. Otherwise, the federal "residuary" power appears to be available, enabling unilateral legislation.

Again, if section 4 of the Senate and House of Commons Act ${ }^{40}$ (enacted under the authority of what is now ${ }^{41}$ section 18 of the Constitution Act, 1867) governing the privileges, immunities, and powers of the Senate and House of Commons and their members, forms part of "the Constitution of Canada," it becomes necessary to consider the relative scope of sections 44 (empowering the federal parliament, subject inter alia to section 42, to "make law amending the Constitution of Canada in relation to . . the Senate") and 42(1)(b) (providing that an "amendment to the Constitution of Canada in relation to" inter alia "(b) the powers of the Senate . . ." may be enacted only in accordance with the procedures prescribed in section 38(1)) of the Constitution Act, 1982). The two sections differ radically.

These may seem, to anyone save a specialist in Canadian public law, to be rather arcane illustrations. So I shall conclude this part of my discussion with a matter of obviously great importance - the constitutional position of the Supreme Court of Canada, which is the "General Court of Appeal for Canada" created by the Parliament of Canada pursuant to the Act of 1867. Section 101 of the Act of 1867 provides, "The Parliament of Canada may, notwithstanding anything in this Act, from Time to Time provide for the Constitution, Maintenance, and Organization of a General Court of Appeal for Canada, and for the Establishment of any additional Courts for the better Administration of the Laws of Canada."42

Whether the whole or any part of this plenary authority of Parliament to legislate as to the Supreme Court of Canada has survived the Constitution Act, 1982, is less' than clear on the face of the latter act. The procedures for amending "the Constitution of Canada" as to matters pertaining to the Court, as these procedures are set out in the Constitution Act, 1982, are far more arduous than the unilateral federal power contemplated by the drafters of the Act of 1867 . Under section 41 of the Constitution Act, 1982, an "amendment to the Constitution of Canada in relation to . . . (d) the composition of the Supreme Court of Canada" requires a proclamation by the Governor General authorized by the Senate and House of Commons - or by the Commons alone under section 47(1) - and by the legislative

40. Can. Rev. Stat., ch. S-8 (1970).

The Senate and the House of Commons respectively, and the members thereof respectively, hold, enjoy and exercise,

(a) such and the like privileges, immunities and powers as, at the time of the passing of the British North America Act, 1867, were held, enjoyed and exercised by the Commons House of Parliament of the United Kingdom, and by the members thereof, so far as the same are consistent with and not repugnant to that Act; and

(b) such privileges, immunities and powers as are from time to time defined by Act of the Parliament of Canada, not exceeding those at the time of the passing of such Act held, enjoyed and exercised by the Commons House of Parliament of the United Kingdom and by the members thereof respectively.

41. The original section 18 of the British North America Act, 1867, 30 \& 31 Vict., ch. 3 (U.K.), was repealed and replaced by the Parliament of Canada Act, 1875, 38 \& 39 Vict., ch. 38 (U.K.), $\S 1$.

42. British North America Act, 1867, 30 \& 31 Vict., ch. 3 (U.K.), § 101. 
assembly of every province. Under section 42(1), an "amendment to the Constitution of Canada in relation to ... (d) subject to paragraph 41(d), the Supreme Court of Canada" requires a proclamation by the Governor General authorized by the Senate and House of Commons-or by the Commons alone under section 47(1) - and resolutions of the legislative assemblies of at least two-thirds of the provinces that have, in the aggregate, according to the then-latest general census, at least fifty percent of the population of all the provinces.

It is beyond discussion that, prior to the commencement of the Constitution Act, 1982, the Parliament of Canada, under section 101 of the Act of 1867, had legislative authority to make, by simple federal statute, whatever provision it might have thought fit as to the composition of the Supreme Court of Canada, its jurisdiction, or any other aspect of its existence. ${ }^{43}$ The Constitution Act, 1982, does not purport, in express terms, to repeal section 101 of the 1867 Act, whether in whole or in part. Indeed, the former Act's section 53(1), read with the schedule, expressly continues the whole Act of 1867 in force, with exceptions not now material.

The Parliament of Canada has, of course, provided for the constitution and organization of the Supreme Court of Canada. Most of its legislation on the subject is to be found in the Supreme Court Act, ${ }^{44}$ some of the most important provi-

43. See, e.g., Attorney-Gen. of Ontario v. Attorney-Gen. of Canada, 1947 A.C. 127 (P.C.); Crown Grain Co. v. Day, 1908 A.C. 504, 506 (P.C.).

44. Can. Rev. Stat., ch. S-19 (1970).

The COURT

3. The court of common law and equity in and for Canada now existing under the name of the Supreme Court of Canada is hereby continued under that name, as a general court of appeal for Canada, and as an additional court for the better administration of the laws of Canada, and shall continue to be a court of record.

THE JUDGES

4. The Supreme Court shall consist of a chief justice to be called the Chief Justice of Canada, and eight puisne judges, who shall be appointed by the Governor in Council by letters patent under the Great Seal.

5. Any person may be appointed a judge who is or has been a judge of a superior court of any of the provinces of Canada, or a barrister or advocate of at least ten years standing at the bar of any of the provinces.

6. At least three of the judges shall be appointed from among the judges of the Court of Appeal, or of the Superior Court, or the barristers or advocates of the Province of Quebec.

7. No judge shall hold any other office of emolument either under the Government of Canada or under the government of any province of Canada.

8. The judges shall reside in the National Capital Region described in the schedule to the National Capital Act or within twenty-five miles thereof.

9. (1) Subject to subsection (2), the judges hold office during good behaviour, but are removable by the Governor General on address of the Senate and House of Commons.

(2) A judge ceases to hold office upon attaining the age of seventy-five years.

\section{SESSIONS AND QUORUM}

25. Any five of the judges of the Supreme Court shall constitute a quorum and may lawfully hold the Court.

26. It is not necessary for all the judges who have heard the argument in any case to be present in order to constitute the Court for delivery of judgment in that case, but in the absence of any judge, from illness or any other cause, judgment may be delivered by a majority of the judges who were present at the hearing.

27. (1) Any judge who has heard the case and is absent at the delivery of judgment, may hand his opinion in writing to any judge present at the delivery of judgment, to be read or announced in open court, and then to be left with the Registrar or reporter of the Court. 


\section{sions of which are set out below. Other provisions pertaining to the Court are to}

(2) A judge who has resigned his office, or who has ceased to hold office under section 9 shall, within six months thereafter, for the purposes of this section, be deemed to be absent at the delivery of judgment in any case heard by him in which judgment has not been delivered during his tenure of office.

28. (1) No judge against whose judgment an appeal is brought, or who took part in the trial of the cause or matter, or in the hearing in a court below, shall sit or take part in the hearing of or adjudication upon the proceedings in the Supreme Court.

(2) In any cause or matter in which a judge is unable to sit or take part in consequence of this section, any four of the other judges of the Supreme Court constitute a quorum and may lawfully hold the Court.

29. Any four judges constitute a quorum and may lawfully hold the Court in cases where the parties consent to be heard before a court so composed.

30. (1) Where at any time there is not a quorum of the judges of the Supreme Court available to hold or continue any session of the Court, owing to a vacancy or vacancies, or to the absence through illness or on leave or in the discharge of other duties assigned by statute or order in council, or to the disqualification of a judge or judges, the Chief Justice, or, in his absence, the senior puisne judge, may in writing request the attendance at the sittings of the Court, as an ad hoc judge, for such period as may be necessary, of a judge of the Federal Court, or, should the judges of that court be absent from Ottawa or for any reason unable to sit, of a judge of a provincial superior court to be designated in writing by the Chief Justice or in his absence by any acting chief justice or the senior puisne judge of such provincial court upon such request being made to him in writing.

(2) Unless two of the judges of the Supreme Court available fulfil the requirements of section 6 , the ad hoc judge for the hearing of an appeal from a judgment rendered in the Province of Quebec shall be a judge of the Court of Appeal or a judge of the Superior Court of that Province designated as above provided.

\section{APPELLATE JURISDICTION}

35. The Supreme Court shall have, hold and exercise an appellate, civil and criminal jurisdiction within and throughout Canada.

41. (1) Subject to subsection (3), an appeal lies to the Supreme Court from any final or other judgment of the highest court of final resort in a province, or a judge thereof, in which judgment can be had in the particular case sought to be appealed to the Supreme Court, whether or not leave to appeal to the Supreme Court has been refused by any other court, where, with respect to the particular case sought to be appealed, the Supreme Court is of the opinion that any question involved therein is, by reason of its public importance or the importance of any issue of law or any issue of mixed law and fact involved in such question, one that ought to be decided by the Supreme Court or is, for any other reason, of such a nature or significance as to warrant decision by it, and leave to appeal from such judgment is accordingly granted by the Supreme Court.

(2) Leave to appeal under this section may be granted during the period fixed by section 64 or within thirty days thereafter or within such further extended time as the Supreme Court or a judge may either before or after the expiry of the thirty days fix or allow.

(3) No appeal to the Supreme Court lies under this section from the judgment of any court acquitting or convicting or setting aside or affirming a conviction or acquittal of an indictable offence or, except in respect of a question of law or jurisdiction, of an offence other than an indictable offence.

(4) Whenever the Supreme Court has granted leave to appeal, the Supreme Court or a judge may, notwithstanding anything in this Act, extend the time within which the appeal may be allowed.

42. Notwithstanding anything in this Act, the Supreme Court has jurisdiction as provided in any other Act conferring jurisdiction.

\section{Judgment Final and Conclusive}

54. (1) The Supreme Court shall have, hold and exercise exclusive ultimate appellate civil and criminal jurisdiction within and for Canada; and the judgment of the Court is, in all cases, final and conclusive.

(2) Notwithstanding any royal prerogative or anything contained in any Act of the Parliament of the United Kingdom or any Act of the Parliament of Canada or any Act of the legislature of any province of Canada or any other statute or law, no appeal lies or shall be brought from or in respect of the judgment of any court, judge or judicial officer in Canada to any court of appeal, 
be found in the Rules ${ }^{45}$ made under the Act, and in other statutes, numbering perhaps two dozen, such as the Bankruptcy $\mathrm{Act}^{46}$ and the Criminal Code, ${ }^{47}$ which latter includes the sections on Supreme Court jurisdiction also set out below. ${ }^{48}$

tribunal or authority by which, in the United Kingdom, appeals or petitions to Her Majesty in Council may be ordered to be heard.

(3) The Judicial Committee Act, 1833, chapter 41 of the statutes of the United Kingdom of Great Britain and Ireland, 1833, and The Judicial Committee Act, 1844, chapter 69 of the statutes of the United Kingdom of Great Britain and Ireland, 1844, and all orders, rules or regulations made under those Acts are repealed in so far as they are part of the law of Canada.

\section{SPECIAL JURISDICTION}

References by Govemor in Council

55. (1) Important questions of law or fact concerning

(a) the interpretation of the British North America Acts;

(b) the constitutionality or interpretation of any federal or provincial legislation;

(c) the appellate jurisdiction as to educational matters, by the Brilish North America Act, 1867, or by any other Act or law vested in the Governor in Council;

(d) the powers of the Parliament of Canada, or of the legislatures of the provinces, or of the respective governments thereof, whether or not the particular power in question has been or is proposed to be exercised; or

(e) any other matter, whether or not in the opinion of the Court ejusdem generis with the foregoing enumerations, with reference to which the Governor in Council sees fit to submit any such question;

may be refërred by the Governor in Council to the Supreme Court for hearing and consideration; and any question concerning any of the matters aforesaid, so referred by the Governor in Council, shall be conclusively deemed to be an important question.

(2) Where a reference is made to the Court under subsection (1) it is the duty of the Court to hear and consider it, and to answer each question so referred; and the Court shall certify to the Governor in Council, for his information, its opinion upon each such question, with the reasons for each answer; and the opinion shall be pronounced in like manner as in the case of a judgment upon an appeal to the Court; and any judge who differs from the opinion of the majority shall in like manner certify his opinion and his reasons.

(3) Where the question relates to the constitutional validity of any Act that has heretofore been or is hereafter passed by the legislature of any province, or of any provision in any such Act, or in case, for any reason, the government of any province has any special interest in any such question, the attorney general of the province shall be notified of the hearing, in order that he may be heard if he thinks fit.

(4) The Court has power to direct that any person interested, or, where there is a class of persons interested, any one or more persons as representatives of such class, shall be notified of the hearing upon any reference under this section, and such persons are entitled to be heard thereon. (5) The Court may, in its discretion, request any counsel to argue the case as to any interest that is affected and as to which counsel does not appear, and the reasonable expenses thereby occasioned may be paid by the Minister of Finance out of any moneys appropriated by Parliament for expenses of litigation.

References by Senate or House of Commons

56. The Court, or any two of the judges thereof, shall examine and report upon any private bill or petition for a private bill presented to the Senate or House of Commons, and referred to the Court under any rules or orders made by the Senate or House of Commons.

45. Rules of the Supreme Court of Canada, Con. REg. CaN., ch. 1512 (1978). (New Rules of the Supreme Court of Canada, made on Jan. 11, 1983, will be valid only so far as consistent with the Constitution Act, 1982. See SOR/82-74, 117 Can. Gaz. 380 (1983).)

46. CaN. ReV. Stat, ch. B-3, $\$$ 164-67 (1970).

47. Can. Rev. Stat., ch. C-34 (1970).

48. 618. (1) A person who is convicted of an indictable offence and whose conviction is affirmed by the court of appeal may appeal to the Supreme Court of Canada

(a) on any question of law on which a judge of the court of appeal dissents, or (b) on any question of law, if leave to appeal is granted by the Supreme Court of Canada within twenty-one days after the judgment appealed from is pronounced or within such extended time as the Supreme Court of Canada or a judge thereof may, for special reasons, allow.

(2) A person 
It is important to note that none of these statutory provisions-not those in the Supreme Court Act nor those in the Criminal Code-are enumerated as part of the "Constitution of Canada" in the schedule of the Constitution Act, 1982. Yet section 53(1) of the latter Act, as shown above, does not make that enumeration exhaustive. If, and to the extent that, any or all of the provisions in question are part of the "Constitution of Canada," they can, clearly, be altered only in compliance with the elaborate formulae prescribed in sections 41 (d) and 42(1)(d) of the Constitution Act, 1982. Indeed, in the cases of sections 6 and 30(2) of the Supreme Court Act, concerning judges from Quebec, ${ }^{49}$ quoted earlier, it is at least arguable that section 43 of the Constitution Act, 1982, applies prima facie; if so, there arise difficult questions as to the nature of section 43 and its relationship to the other procedures-both generally and in the specific matter of the Supreme Court of Canada. Would repeal of section 6 of the Supreme Court Act be possible: (i) by unilateral federal statute under section 101 of the Act of 1867? (ii) by the procedure prescribed by section 41 (d) of the Constitution Act, 1982? (iii) by the procedure prescribed by section 42(1)(d) of the Constitution Act, 1982? (iv) by the procedure prescribed by section 43 of the Constitution Act, 1982?

To argue that none of the federal statute law dealing with the Supreme Court of Canada forms part of the "Constitution of Canada" is to say, in effect, that Parliament may continue to legislate on the subject exactly as it pleases; and that its power under section 101 of the 1867 Act to do so cannot be taken away save by the elaborate methods newly prescribed by Part V of the Constitution Act, 1982. This can scarcely have been what the eight "opposing" premiers had in mind when they signed their "April Accord"50 from which sections 41(d) and 42(1)(d) were taken. Yet this construction is not, on its face, an impossible one.

On the other hand, if all federal statute law on the subject of the Supreme Court of Canada forms part of the "Constitution of Canada," it is not obvious why amendment of any of the Rules of the Supreme Court of Canada is not equally subject to the procedure prescribed by section $42(1)(d)$ of the Constitution Act,

(a) who is acquitted of an indictable offence other than by reason of the special verdict of not guilty on account of insanity and whose acquittal is set aside by the court of appeal, or

(b) who is tried jointly with a person referred to in paragraph (a) and is convicted and whose conviction is sustained by the court of appeal, may appeal to the Supreme Court of Canada on a question of law.

620. (1) A person who has been found not guilty on account of insanity and

(a) whose acquittal is affirmed on that ground by the court of appeal, or

(b) against whom a verdict of guilty is entered by the court of appeal under subparagraph 613(4)(b)(i), may appeal to the Supreme Court of Canada.

(2) A person who is found unfit, on account of insanity, to stand his trial and against whom that verdict is affirmed by the court of appeal may appeal to the Supreme Court of Canada.

(3) An appeal under subsection (1) or (2) may be

(a) on any question of law on which a judge of the court of appeal dissents, or

(b) on any question of law, if leave to appeal is granted by the Supreme Court of Canada within twenty-one days after the judgment appealed from is pronounced or within such extended time as the Supreme Court of Canada or a judge thereof may, for special reasons, allow.

See supra note 44

49. See supra note 44 .

50. See supra note 13 . 
1982. One such rule provides, "The covers of the appellants' factum shall be coloured buff and the covers of the respondents' factum shall be coloured green." 1 Such a position would be tantamount to holding that sections 41 (d) and 42(1)(d) of the Constitution Act, 1982, have impliedly repealed so much of section 101 of the Act of 1867 as concerns the "General Court of Appeal for Canada." The rule of statutory construction pertaining to implied repeal was perhaps best stated by Rt. Hon. Dr. Lushington in The India (No. 2):

\begin{abstract}
What words will constitute a repeal by implication it is impossible to say from authority or decided cases. If, on the one hand, the general presumption must be against such a repeal, on the ground that the intention to repeal, if any had existed, would have been declared in express terms; so on the other, it is not necessary that any express reference be made to the statute which is to be repealed. The prior statute would I conceive be repealed by implication, if its provisions were wholly incompatible with a subsequent one, or, if the two statutes together would lead to wholly absurd consequences, or if the entire subjectmatter were taken away by the subsequent statute. Perhaps the most difficult case for consideration is where the subject-matter has been so dealt with in subsequent statutes, that, according to all ordinary reasoning, the particular provision in the prior statute would not have been intended to subsist, and yet if it were left subsisting no palpable absurdity would be occasioned. ${ }^{52}$
\end{abstract}

The Supreme Court of Canada will likely be disposed to adopt an intermediate position, attributing to some of the federal statutory provisions a "constitutional" character, and to others not. This would give an entrenched status to the essential elements of the court's character, without involving the inconvenience which an implied repeal of the pertinent portion of section 101 would entail. On the other hand, it would show very clearly just how uncertain in law is the phrase "the Constitution of Canada" as it appears in Part V of the 1982 Act.

The phrase "the constitution of the province" appears in section 45 of the Constitution Act, 1982, which provides that, subject to section 41, "the legislature of each province may exclusively make law amending" it. Section 45 , of course, establishes a distinct amending procedure in its own right, and it will be convenient to treat it as such. Suffice it for the moment to say that the "constitution of the province," roughly speaking, is the body of law governing the provinces' executive and legislative institutions.

Are the phrases "Constitution of Canada" and "constitution of the province" mutually exclusive? Arguably, they are not. In my view, the constitution of every province is part of the "Constitution of Canada" as that phrase appears in Part V of the 1982 Act. The heading of Part V, which embraces section 45, is indeed "Procedure for Amending Constitution of Canada." And there is other textual evidence pointing in the same direction. Thus section 45 is subordinated to section 41 and section 41 (c) refers to section 43-notably, to section 43(b). This appears to imply that a constitutional provision respecting the use of the English and French languages can, at one and the same time, be both part of the constitution of a province and also part of the Constitution of Canada.

51. Rules of the Supreme Court of Canada, CoN. REg. CAN., ch. 1512, R. 32(2) (1978). Under the new Rules (supro note 45) "the cover of the intervener's factum shall be blue": Rule 39(2). Is this validly enacted?

52. 167 Eng. Rep. 345, 346 (Adm. 1864). 
This issue is of considerable importance in determining how far the various procedures of Part $\mathrm{V}$ are mutually exclusive: in particular, how far sections 38 and 45 are mutually exclusive. I shall return to this question in section $X$.

\section{IV}

\section{The Amending Procedures and the Participants}

\section{A. The Amending Procedures}

I propose to denominate the amending procedures established by Part $\mathrm{V}$ of the Constitution Act, 1982, as follows: (i) the "general" procedure (section 38, with which may be read section 42); (ii) the "unanimous consent" procedure (section 41); (iii) the "special arrangements" procedure (section 43); (iv) the "unilateral federal" procedure (section 44); and (v) the "unilateral provincial" procedure (section 45). The first two descriptions are suggested by the marginal notes to the statute; the others are of my own choosing.

Before proceeding to analyze each amending formula individually, I shall first consider some attributes common to all of them.

\section{B. The Participants}

1. The Crown. The Sovereign or her representative (federally, the Governor General of Canada and provincially, the Lieutenant Governor of the province) is a necessary participant in all the amending procedures of Part V. The "unilateral" procedures contemplate Acts of Parliament of Canada C $^{53}$ and of the provincial legislatures. ${ }^{54}$ In each such instance royal assent, given personally by the Sovereign or through her representative, is legally indispensable. ${ }^{55}$ The other amending procedures of Part V, sections 38(1), 41, and 43, all require a "proclamation issued by the Governor General under the Great Seal of Canada."

In the Canadian constitutional system-at the federal level at any rate-both supreme executive power and coordinate legislative power are vested directly in the person of the Sovereign, ${ }^{56}$ and are exercisable by her representative only by delegation. ${ }^{57}$ It thus appears asymmetrical, and even unseemly, for Part $V$ to confer upon the subordinate directly-rather than initially upon the principal - the ultimate lawmaking power: the power of enactment of constitutional amendments after the necessary consents have been secured.

53. Constitution Act, 1982, 1982 ch. 11 (U.K), Sch. B $\S 44$.

54. Id. $\$ 45$.

55. See Constitution Act, 1867, 30 \& 31 Vict., ch. 3 (U.K.), $\$ \S 17,55-57,91$ (requiring assent, expressly or by inference, for federal legislation); id. $\$ \S 58-59,64-65,69-90,88$ (for provincial legislation). The same result follows for the provinces admitted since 1867 in virtue of the enactments and other instruments establishing them. See also In re Initiative and Referendum Act, 1919 A.C. 935, 944-45 (P.C.); Liquidators of Maritime Bank of Canada v. Receiver-General of New Brunswick, 1892 A.C. 437, 444 (P.C.).

56. See Constitution Act, 1867, 30 \& 31 Vict., ch. 3 (U.K.), §§ 9, 17, 91.

57. The Governor-General appears to derive his authority to assent to bills directly from the statute; its exercise, however, is subject at least to the Sovereign's control by instruction, and probably to restriction by prerogative instrument. See Constitution Act, 1867, 30 \& 31 Vict., ch. 3 (U.K.), §55. See Scott, Entrenchment by Executive Action: A Partial Solution to "Legislative Override", 4 SUPREME COURT L. REV. 303 (1982). 
No doubt, in contemplation of law the act of the Governor General in amending the Constitution of Canada is the act of the Sovereign.58 Yet there are serious questions as to whether the Sovereign could act personally; whether a federal statute (enacted, for example, under section 45) could empower the Sovereign to act personally; and whether the Sovereign could, as a matter of law, impose restrictions upon the power of her subordinate to make constitutional amendment proclamations. However these problems be resolved (and even assuming the resolution most favourable to the status and dignity of the Crown), it seems most objectionable that the Sovereign's position should be impaired in this disrespectful way, which was in my view quite deliberate.

Section 48 shows some concern about the proprieties in that it imposes its novel (and unnecessary) duty upon the Queen's Privy Council for Canada to advise issuance of a proclamation, and not upon the Governor General to make a proclamation-an act which he is, in consequence, legally free to refuse to do. It is an interesting question whether section 48 imposes an imperative duty-whether upon the Council as a body or upon its members - and, if so, at whose suit it is enforceable: “The Queen's Privy Council for Canada shall advise the Governor General to issue a proclamation under this Part forthwith on the adoption of the resolutions required for an amendment made by proclamation under this Part."59

2. The Houses of the Parliament of Canada. The concurrence of the House of Commons of Canada is an essential requirement of all the amending procedures of Part V, save only the "unilateral provincial" procedure.

What, then, of the upper house of the federal parliament, the Senate?60 The Senate is, of course, in law a co-ordinate legislative body of the Parliament of Canada. ${ }^{61}$ Indeed, its position as such cannot from now on be impaired save in accordance with section 42(1)(b) of the Constitution Act, 1982: that is, save through the "general" procedure of section 38(1). Accordingly, the Senate's concurrence is obviously necessary to any exercise of the "unilateral" federal amending power of section 44 .

58. In Liquidators of Maritime Bank of Canada v. Receiver-General of New Brunswick, 1892 A.C. 437, the Privy Council held that, in the absence of express words to the contrary, the Crown must be presumed to be a necessary party to legislation. Id. at 443; see also Reference re Power of Disallowance, 1938 S.C.R. 71, 76 (Can.) ("The act of a Lieutenant-Governor in assenting to a bill or in reserving a bill is an act of the Crown by the Crown's representative just as the act of the Governor General in assenting to a bill or reserving a bill is the act of the Crown."-per Duff, C.J.); In re Initiative and Referendum Act, 1919 A.C. 935 (P.C.).

59. Constitution Act, 1982, 1982 ch. 11 (U.K.), Sch. B $\$ 48$.

60. Senators, it will be recalled, are appointed by the federal executive government, and (if appointed after June 1, 1965) hold office until the age of seventy-five. (Senators formerly held office for life.) Representation is on a regional basis, with twenty-four Senators representing Ontario, twenty-four representing Quebec, twenty-four for the Maritime Provinces (ten each for Nova Scotia and New Brunswick, and four for Prince Edward Island), and twenty-four for the Western provinces (six each for Manitoba, British Columbia, Saskatchewan, and Alberta). Six have been added for Newfoundland, and one each for the Yukon Territory and the Northwest Territories.

On the position of the Senate of Canada, see generally Constitution Act, 1867, 30 \& 31 Vict., ch. 3 (U.K.), \$§ 17-18, 21-36, 53.

61. Id. $\$ \S 17,91$. 
The Senate's role in the other amending procedures-be they "multilateral"62 or even in some cases "bilateral" 63 _has been reduced, by section 47 , to a sixmonth delaying power:

47. (1) An amendment to the Constitution of Canada made by proclamation under section $38,41,42$ or 43 may be made without a resolution of the Senate authorizing the issue of the proclamation if, within one hundred and eighty days after the adoption by the House of Commons of a resolution authorizing its issue, the Senate has not adopted such a resolution and if, at any time after the expiration of that period, the House of Commons again adopts the resolution.

(2) Any period when Parliament is prorogued or dissolved shall not be counted in computing the one hundred and eighty day period referred to in subsection (1).

In the original proposal of October 2, 1980,64 the Senate was given co-ordinate authority with the House of Commons where a referendum was to be employed; 65 but in other cases ${ }^{66}$ the Senate was to enjoy only a ninety-day delaying power.

In the revised proposal of April 24, 1981, the Senate had full co-ordinate power in all cases. A beleaguered federal government was in no position to press forward to Westminster, not only against the opposition of eight provinces, but without the concurrence of the upper house in the traditional joint address to the Queen. Coordinate power for the Senate was in effect to be the price of the Senate's cooperation.

With the federal-provincial agreement of November 5, 1981, the Senate was no longer able, as a practical matter, to insist on retaining full co-ordinate authority in the whole constitutional amendment process, not even (perhaps especially not) where its own existence or constitution or powers were involved. On the other hand, subsections 42(1)(b) and (c) provide the Senate with a substantial degree of entrenchment.

3. Provincial Legislative Assemblies. All the procedures of Part V, save only the "unilateral federal" procedure, require the concurrence of bodies forming part of provincial "representative" legislatures. In the case of the three new-style formulae involving Governor Generals' proclamations-that is, the "general" procedure of section 38, the "unanimous consent" procedure of section 41 , and the "special arrangements" procedure of section 43-the concurrence of the "legislative assembly" of one or more provinces is required. "Legislative assembly" is a term which ought to have been defined, particularly since the provinces are free under section 45 to have bicameral or multicameral legislatures and, indeed, largely free to prescribe the mode of selection of members of all or any of the bodies forming part of such legislatures. It would have been preferable to have attempted something along these lines:

In Part V, the "legislative assembly" of a province is the only deliberative legislative

62. Constitution Act, 1982, 1982 ch. 11 (U.K.), Sch. B $\S \S 38(1), 41$.

63. See id., $\S 43$. This assumes that $\S 43$ does in truth create a distinct amending procedure. See infra

Pt. VII.

64. See supra note $6, \S 42$.

65. Id. $\S 44$, applying this rule to $\$ \$ 41(1)$ and 43 .

66. See supra note $12, \S \S 46,47,48$ and 49 . 
body or the most numerous deliberative legislative body having at least full co-ordinate power, forming part of the provincial legislature.

Nevertheless, if the legislature includes one or more such bodies consisting only of elected representative members, the "legislative assembly" is that body, or the most numerous such body.

When two or more bodies qualify equally, and are equally numerous, any one may act to propose or to consent to a constitutional amendment, and all must act to withdraw or revoke it.

The last provincial legislative upper house disappeared from Canada on December 31, 1968, the day on which the Legislative Council of Quebec was abolished by a simple provincial statute, ${ }^{67}$ enacted - under the authority of section 92.1 of the Act of 1867-by the Crown, the Legislative Council, and the Legislative Assembly. All Canadian provincial legislatures are now unicameral. Their single chambers are wholly elected; therefore, de facto, the term "legislative assembly" in Part V of the 1982 Act offers at present no difficulty of application.

Again, the term "legislature," where it appears in section 45 of the 1982 Act (the "unilateral provincial" amendment procedure, successor to section 92.1 of the $1867 \mathrm{Act}$ ) means the Sovereign, or her representative, acting with the other lawfully-prescribed elements of the provincial lawmaking process. Apart from the Sovereign's concurrence through royal assent, the law in every province requires, in order that a bill may become law, only due passage by the provincial legislative assembly. So, effectively, the term "legislature" in section 45 means, for the present, "Crown and provincial legislative assembly."

4. The Referendum and Its Disappearance. Under the federal proposals concerning constitutional amendment procedures, as they were referred to the Supreme Court of Canada on April 24, 1981, provincial consent to constitutional amendments could, in this scheme, be given by a majority of provincial legislative assemblies meeting stated criteria to ensure adequate representation of all regions (and concurrence of both Quebec and Ontario). ${ }^{68}$ But provincial consent could alternatively be given by the Canadian electorate provided that the national refer-

67. An Act Respecting the Legislative Council, 17 Eliz. 2, ch. 9 (S. Que. 1968).

68. The essence of the federal proposals concerning constitutional amendment procedures, as those proposals stood on April 24, 1981 , and as they were referred to the Supreme Court of Canada, may be seen in these two provisions:

46. (1) An amendment to the Constitution of Canada may be made by proclamation issued by the Governor General under the Great Seal of Canada where so authorized by

(a) resolutions of the Senate and House of Commons; and

(b) resolutions of the legislative assemblies of at least a majority of the provinces that includes

(i) every province that at any time before the issue of the proclamation had, according to any previous general census, a population of at least twenty-five per cent of the population of Canada,

(ii) two or more of the Atlantic provinces, and

(iii) two or more of the Western provinces.

(2) In this section,

"Atlantic provinces" means the provinces of Nova Scotia, New Brunswick, Prince Edward Island and Newfoundland;

"Western provinces" means the provinces of Manitoba, British Columbia, Saskatchewan and Alberta.

47. (1) An amendment to the Constitution of Canada may be made by proclamation issued 
endum majority included also referendum majorities in provinces whose assemblies' consent would have sufficed as provincial approval. (The consent of the federal Houses would remain necessary in any event.)

By contrast, the constitutional amendment processes prescribed by Part $\mathrm{V}$ of the Constitution Act, 1982, all involve action by the Sovereign, or by the Governor General (presumably as the Sovereign's representative)-and by federal and provincial deliberative legislative bodies acting in various combinations.

Participation of the electorate directly through referendum-so prominent in the proposal of October 2, $1980,{ }^{69}$ and its ultimate revision of April 24, $1981^{70}$ has, in consequence of the November 5, 1981, agreement, ${ }^{71}$ disappeared completely. This development is one of far-reaching significance.

During the course of public debate, no aspect of the federal proposal-not even the entrenchment of a charter of rights and freedoms-drew remotely as bitter a response from provincial authorities-from Newfoundland to Western Canadaas did the inclusion of the referendum process. Why?

The amending formula proposed in October 1980 and that which emerged in revised form in April 1981 both imposed stringent conditions as to the number and the grouping of provinces whose consent would be needed to effect constitutional amendments of various kinds. Most notably, these conditions controlled amendments bearing on the distribution of legislative powers as between the federal and provincial authorities. In particular, for a general amendment to become law, the consent of Quebec and Ontario would have been required (each having had, at some time, at least twenty-five percent of the population of Canada). Such a provision was an obvious euphemism for giving Quebec a veto and for conceding that whatever Quebec has, Ontario, too, must be given.

The federal government apparently expected-and in my view, rightly

by the Governor General under the Great Seal of Canada where so authorized by a referendum held throughout Canada under subsection (2) at which

(a) a majority of persons voting thereat, and

(b) a majority of persons voting thereat in each of the provinces, resolutions of the legislative assemblies of which would be sufficient, together with resolutions of the Senate and House of Commons, to authorize the issue of a proclamation under subsection $46(1)$.

have approved the making of the amendment.

(2) A referendum referred to in subsection (1) shall be held where directed by proclamation issued by the Governor General under the Great Seal of Canada, which proclamation may be issued where

(a) an amendment to the Constitution of Canada has been authorized under paragraph $46(1)$ (a) by resolutions of the Senate and House of Commons;

(b) the requirements of paragraph $46(1)(b)$ in respect of the proposed amendment have not been satisfied within twelve months after the passage of the resolutions of the Senate and House of Commons; and

(c) the issue of the proclamation has been authorized by the Governor General in Council.

(3) A proclamation issued under subsection (2) in respect of a referendum shall provide for the referendum to be held within two years after the expiration of the twelve month period referred to in paragraph (b) of that subsection.

69. See supra note $6, \S 42$.

70. See supra note $12, \S 47$.

71. See supra note 13. 
expected-the electorate, even in Quebec (perhaps especially in Quebec), to be more pliable than would be any elected provincial assembly in passing judgment on proposals from Ottawa for constitutional amendments. This would be particularly true where the balance of power within the federation was concerned. The voters would more readily give the consent of the province than would their provincial representatives.

After all, the Quebec electorate had, in the May 20, 1980, provincial referendum, refused the Parti Québécois provincial government its desired mandate to negotiate the independence of Quebec. Yet, on April 13, 1981, the same voters returned the same government to power, no less committed to its purpose of independence. This was a recent, and clear, demonstration of the way in which the Quebec electorate, speaking directly, could be expected to be more attached to, and sympathetic to, federal institutions than would a provincial legislature. But such a phenomenon would not be confined to Quebec alone. In any province, provincial legislators would probably cling to provincial jurisdiction with greater tenacity than would their electorate.

A difference in attitudes, flowing from their different positions, may naturally be expected between provincial voters and provincial representatives. But beyond this, the electoral system in itself may play an important psychological role in provincial legislators' attitudes toward constitutional amendments.

In Quebec that phenomenon can be expected to work in the following way. Of provincial political parties, the "more nationalist" party or parties will oppose "centralization" on principle. The "less nationalist" party or parties will oppose "centralization" out of fear that their opponents will effectively exploit the "national" or "provincial autonomy" issue. Moreover, elections often turn on "swing" votes: certain positions endanger marginal votes. Furthermore, nonFrench-Canadian voters-far more likely statistically to have a "federalist" political orientation-do not find the effect of their votes diluted in referenda; whilst, given their geographical concentration, their votes are greatly diluted in elections to the provincial legislature. All this points to referenda as being more favourable to federal interests than are provincial legislative assemblies.

Although Mr. Trudeau and his colleagues may not have worked the theory out quite so fully as this, they clearly perceived that: (1) at least in the Canadian political context, a referendum, inserted in the amending formula as an alternative means of securing the necessary provincial consents, would be an element of flexibility; (2) the more rigid the amending formula in other respects, the more this element of flexibility was needed; and (3) the flexibility derived from a referendum would be favourable to federal interests, particularly as no referendum could be held without the consent of the Senate and House of Commons of Canada. ${ }^{72}$

The provincial premiers and the federal opposition leader grasped the implica-

72. The October 2, 1980 scheme marked the first appearance of the referendum in the text of a proposed amending formula. This author suggested something similar in September 1964. Wishing to alleviate the rigours of the proposed "Fulton-Favreau Formula" (requiring unanimous provincial consent for most important constitutional amendments), this author advanced the idea that, in any amending 
tions of the referendum element from the start. Of the eight premiers who opposed the October 1980 package, virtually all made a special point of attacking the referendum specifically, or of attacking the package generally with the referendum obviously in mind. The language was sometimes envenomed, and the complaint was that the referendum was "centralizing." It was indeed more "centralizing" than a formula without it. Provincial autonomy was not safe in the hands of provincial electors-at any rate, it was much less safe than in the premiers' own hands. Whatever in Mr. Trudeau's proposals might by any possibility have survived the Supreme Court's decision of September 28, 1981, the referendum could never have done so. In fact, it did not.

\section{Initiation of Amending Procedures}

All the amending procedures may be "initiated" by any of the participating legislative chambers. The "unilateral" procedures-assuming bicameralism or multicameralism-will of course be subject to the normal rule that bills may be introduced in any of two or more co-ordinate legislative bodies. For the other procedures of Part V of the Constitution Act, 1982, section 46(1) makes it explicit that " $[\mathrm{t}]$ he procedures for amendment under sections 38, 41, 42 and 43 may be initiated either by the Senate or the House of Commons or by the legislative assembly of a province."

The power of a provincial legislative assembly to "initiate" constitutional amendments by resolution seems far more likely to be effective than the power, given to an American state legislature by Article $V$ of the United States Constitution, to apply for the calling of a convention, even though the constitutional language seems to impose a duty upon Congress to comply with such a request from the legislatures of two-thirds of the states. Of course, the Canadian federal Houses can ignore provincial resolutions-just as the provincial assemblies can ignore those coming from Ottawa. But, as a matter of comity, the formal proposal of an amendment by a resolution enjoying legal status seems to command the attention of the other participants, and to demand at least due consideration. It will be interesting to see whether the federal government will feel obliged to provide parliamentary time to debate resolutions coming from provincial assemblies.

\section{Revocation of Resolutions of Assent}

Section 46(2) of the 1982 Act settles in the affirmative the question-which otherwise would sooner or later have had to be litigated-whether resolutions of assent to amendments are revocable before the making of the amendment. That section provides that "[a] resolution of assent made for the purposes of this Part may be revoked at any time before the issue of a proclamation authorized by it."73

\footnotetext{
formula, "provincial consent should be capable of being given alternatively by the voters of the province . . . " See Editor's Dian, 12 McGill L.J. 337, 342-43 note (1966-67).

Nothing came of the suggestion. In this century, the federal Liberal Party has been rather effective in getting, and keeping, federal power in Canada. It is astounding to see how slow it has been to grasp an idea at once so likely to advance federal interests and so very obvious.

73. Constitution Act, 1982, 1982 ch. 11 (U.K.), Sch. B $\S 46(2)$.
} 


\section{V \\ The "General" Procedlire}

The marginal note to section 38 of the 1982 Act suggests that this formula be styled the "general procedure" for amending the Constitution of Canada:

38. (1) An amendment to the Constitution of Canada may be made by proclamation issued by the Governor General under the Great Seal of Canada where so authorized by

(a) resolutions of the Senate and House of Commons; and

(b) resolutions of the legislative assemblies of at least two-thirds of the provinces that have, in the aggregate, according to the then latest general census, at least fifty per cent of the population of all the provinces.

(2) An amendment made under subsection (1) that derogates from the legislative powers, the proprietary rights or any other rights or privileges of the legislature or government of a province shall require a resolution supported by a majority of the members of each of the Senate, the House of Commons and the legislative assemblies required under subsection (1).

(3) An amendment referred to in subsection (2) shall not have effect in a province the legislative assembly of which has expressed its dissent thereto by resolution supported by a majority of its members prior to the issue of the proclamation to which the amendment relates unless that legislative assembly, subsequently, by resolution supported by a majority of its members, revokes its dissent and authorizes the amendment.

(4) A resolution of dissent made for the purposes of subsection (3) may be revoked at any time before or after the issue of the proclamation to which it relates.

\section{A. Necessary Number of Consenting Provincial Assemblies.}

An amendment under section 38 requires the consent of two-thirds of the provinces' legislative assemblies. For the moment, that means seven. This at least formally explains the apparent (implied) abrogation ${ }^{74}$ of Parliament's pre-existing unilateral legislative power to create new provinces. ${ }^{75}$ This power could conceivably have been employed to create additional provinces precisely in order to facilitate passage of constitutional amendments under the new procedure. (American history seems to offer at least one close precedent. ${ }^{76}$ ) Even so, the provisions of section 38(2) would surely have given adequate protection to most of the basic provincial interests. It is a fair guess that the Trudeau government did not resist curtailment of federal legislative power to create new provinces because the federal authorities could henceforth more easily resist pressure for the creation of new provinces in the north. The resources of the north are thus more likely to remain a "national" asset with a bigger share remaining for the existing provinces.

74. See Constitution Act, 1982, 1982 ch. 11 (U.K.), Sch. B $\S \S 42(1)(f), 42(2)$.

75. See Constitution Act, 1871, 34 \& 35 Vict., ch. 28 (U.K.), $§ 2$.

76. The state of West Virginia appears to have been created by Congress to further the cause of suppressing the Confederate rebellion against the United States. See, e.g., A. Mclaughlin, A ConstitiTIONAL History OF THE UNITED STATEs 634-38 (1935). A rump government of "Virginia" at Wheeling was recognized as giving the consent of Virginia to the cession of the territory from which Congress erected the new state of West Virginia in the summer of 1863.

The thirteenth amendment to the U.S. Constitution was proposed by Congress on January $31,1865$. West Virginia, the sixth state to ratify, did so three days later, on February 3, 1865, and it was recognized as one of the twenty-seven ratifying states when ratification was complete on December 6,1865 . In itself, this does not prove that West Virginia was erected specifically to ratify the thirteenth amendment. But it seems that West Virginia was erected to co-operate, and did co-operate, with Congressional purposes as regards the Confederacy. 
B. Required Character of Consenting Provincial Assemblies.

Since by its terms the provinces whose assemblies' consent is needed for an amendment must include "provinces that have, in the aggregate, according to the then latest general census, at least fifty percent of the population of all the provinces," population statistics are needed to ascertain compliance with section 38 . The 1976 and 1981 Census figures are these: ${ }^{77}$

\section{TABLE 1}

\section{Population of Canada by Provinces and Territories}

\section{PROVINCE OR TERRITORY}

\section{Alberta}

British Columbia

Manitoba

New Brunswick

Newfoundland

Nova Scotia

Ontario

Prince Edward Island

Quebec

Saskatchewan

Yukon Territory

Northwest Territories

\begin{tabular}{rrr}
1976 Census & 1981 Census \\
$1,838,037$ & $2,237,724$ \\
$2,466,608$ & $2,744,467$ \\
$1,021,506$ & $1,026,241$ \\
677,250 & 696,403 \\
557,725 & 567,681 \\
828,571 & 847,442 \\
$8,264,465$ & $8,625,107$ \\
118,229 & 122,506 \\
& $6,234,445$ & $6,438,403$ \\
& 921,323 & 968,313 \\
& 21,836 & 23,153 \\
& 42,609 & 45,741 \\
\cline { 2 - 3 } [Provinces only & $22,992,604$ & $24,343,181$ \\
& $22,928,159$ & $24,274,287]$
\end{tabular}

\section{Treatment of Provinces on a Uniform Basis.}

The rules governing the number and character of the provinces whose assemblies' consent is needed for an amendment under section 38 can be said, with a plausibility formerly impossible, to put all provinces on an "equal" footing or to apply "fair" or "uniform" criteria. The veto power sought to be conferred upon Quebec and Ontario ${ }^{78}$ has been eliminated. It had formerly been accepted that a "veto" could not be refused to Quebec and that whatever Quebec had, Ontario, too, must be given. Needless to say, this was increasingly resisted in western Canada, where some of the provinces began to assert a claim to the like veto. In the end, the power of "dissent" replaced the veto.

D. Majorities Required to Pass Resolutions Derogating from "the legislative powers, the proprietary rights or any other rights or privileges of the legislature or government of a province."

Section 38(2) requires that the resolutions which it contemplates be passed by "a majority of the members of" each of the Senate, the House of Commons, and the legislative assemblies required under subsection (1). It is notable that no similar express condition is to be found in subsection (1) which speaks only of "resolu-

77. For the 1976 figures, see 1981 Canadian Almanac \& Directory 955 (1981). The 1981 Figures have been informally furnished by Statistics Canada, a federal government agency.

78. See, e.g., supra note 68 . 
tions of the legislative assemblies . . . ."As a matter of historical fact, it appears that no difference was in truth intended by the federal parliamentary draftsman, but that provincial legal advisers would not agree to the elimination of the extra phrase.

Of course, a majority of some sort is obviously needed to carry any resolution, even one under section $38(1)$. Normally a statutory quorum will be required, ${ }^{79}$ and the question will then be decided by a majority of persons present and voting. ${ }^{80}$ In the Senate of Canada, the Speaker has an original vote, but no casting vote $;^{81}$ elsewhere, he usually has a casting vote to be exercised on equal division only. ${ }^{82}$ The addition of the extra words "a majority of the members of" involves a prima facie presumption that they are not superfluous, and that they produce a different legal result from that which obtains where (as in section 38(1)) they are not used. If this principle of statutory construction is applied, the question is: what is the special or additional requirement which they add? The only obvious explanation can be that a majority of the whole membership of the house is needed to pass resolutions derogating from provincial powers. It remains an open question as to how vacancies are to be taken into account.

The rule of statutory construction is not an inflexible one, and it may be that the courts will decline to construe section $38(2)$ as creating a class of resolutions which require special majorities of the entire membership of the body. Indeed, uniformity could also be achieved (though justified only with difficulty) by a judicial construction imposing the more stringent, rather than the less stringent, rule in all cases.

Those who may wish to embark on the process of constitutional amendment would do well to secure a judicial clarification at the earliest opportunity. Otherwise lengthy legislative efforts may prove abortive. Indeed, one of the serious practical embarrassments which would result from distinguishing the majority normally required by section 38 (1) from the majority specially required by section $38(2)$ is that the sponsor would be forced from the outset of any journey of amendment, either to secure the special majority in every case, or to judge correctly whether the proposed amendment falls outside the requirements of section $38(2)$ so that the lesser, "normal" majority suffices. If there are two rules and two kinds of majority, one can readily envisage how perplexed parliamentary officers and legal advisers will be when they are faced with a resolution which has been "passed" by the normal majority only, and they must decide what to do next.

\section{E. "Dissent" as a Substitute for Veto.}

Subsections 38(3) and (4) of the Constitution Act, 1982, create and regulate a

79. See Constitution Act, 1867, 30 \& 31 Vict., ch. 3 (U.K.), \$§ 35, 48, (Houses of Parliament); id. $\S \S 87-8 \delta$ (provincial legislatures). Quorum requirements are also to be found in instruments creating the several provinces and in the provincial statutes.

80. See id., $\$ \S 36,49,87-88$. Instruments creating the individual provinces and provincial statutes also contain such requirements.

81. Id. $\S 36$.

82. Id. $§ \S 49,87-88$. 
mechanism whereby the legislative assembly of a province can "dissent" from a proposed amendment "that derogates from the legislative powers, the proprietary rights or any other rights or privileges of the legislature or government of a province" (and can later revoke its "dissent"). Outright veto of constitutional amendments has instead become veto of their application to a particular province. The outright veto had been conceded-at least where provincial rights and powers were to be impaired-to all provinces in the Fulton Formula ${ }^{83}$ and the FultonFavreau Formula ${ }^{84}$ of the sixties. The veto had been effectively limited to Quebec and Ontario in later proposals. ${ }^{85}$

The implications of this substitution were summarized in Mr. Trudeau's phrase "chequerboard Canada." He opposed and resisted it strongly. Although the provision for dissent allows either geographically-selective centralization or decentralization, we shall probably see the former. Were past historical attitudes to be projected into the future, federal jurisdiction would tend to expand with respect to provinces other than Quebec. A "special status" for Quebec could emerge. In Quebec, even amongst French-Canadian nationalists, there seems to be some uncertainty as to whether this would be a good thing. Would it, for example, underscore the necessity, desirability, or feasibility of Quebec independence?

It should be noted that the problem, discussed above, as to the meaning of the phrase "resolution supported by a majority of" members, recurs in respect of the passage $^{86}$ or revocation ${ }^{87}$ of a provincial assembly's resolution of dissent. While provincial representatives in Winnipeg in March 1981 had worked out a formula requiring a two-thirds majority of a provincial assembly to carry a resolution of dissent, the eight premiers-apparently after late-night negotiations-reduced this in their April 16, 1981, Ottawa proposal"8 to "a majority of the Members." The moving force, it appears, was Premier René Lévesque of Quebec, who, in the April 13, 1981, provincial general election-three days earlier-had been returned to power with eighty of the one hundred and twenty-two seats in the Quebec "National Assembly"-two seats short of a two-thirds majority.

\section{F. Compensation to Dissenting Provinces.}

Outright veto of a constitutional proposal to transfer a matter from provincial to federal jurisdiction would, ex hypothesi, prevent the constitutional change from

83. Reprinted in 12 MCGiLL L.J. 576 (1966-67).

84. Reprinted in 12 MCGILL L.J. 579 (1966-67).

85. This was accomplished through the euphemism of giving a veto to every province "that at any time before" the "issue" of a proclamation of amendment "had, according to any previous general census, a population of at least twenty-five percent of the population of Canada": Art. 49, CANADIAN CoNSTITUTIONAL CharTer, being a draft produced by the Constitutional Conference at Victoria, B.C., June 14-16, 1971, reproduced as Appendix B to the Final REPORT of the Special Joint Committee of the Senate and of the House of Commons on the Constitution of Canada (Ottawa, 1972) at 106. See provisions to the same effect in the drafts of October 2, 1980 (supra note 6), $\$ \$ 41$ (1)(b)(i) and 42(1)(b); and April 24, 1981 (supra note 12$), \$ \$ 46(1)(\mathrm{b})(\mathrm{i})$ and $47(1)(\mathrm{b})$.

86. Constitution Act, 1982,1982 ch. 11 (U.K.), Sch. B $§ 39(3)$.

87. Id. subsections 39(3), (4).

88. See Canadian News Facts, Vol. 16, No. 7, at 2490-91, and No. 8, at 2498 (1981). 
occurring at all. "Dissent," on the contrary, is simply an "opting-out," and given the existence of the present ten provinces, up to three can do so without blocking passage of the amendment. For these "dissenting" provinces there are obvious fiscal consequences, since they will continue to support expenditures which the participating provinces will have transferred to the federation. Section 40 of the 1982 Act serves to minimize such consequences by providing, "Where an amendment is made under subsection $38(1)$ that transfers provincial legislative powers relating to education or other cultural matters from provincial legislatures to Parliament, Canada shall provide reasonable compensation to any province to which the amendment does not apply." Section 40 is restricted in scope, covering only "education or other cultural matters." This restriction is a principal point of objection by the Quebec government.

Section 40 suggests the following questions. First, what is a "transfer"? Does creation of a concurrent federal power suffice to bring section 40 into operation? Second, what are "cultural" matters? (This genus includes "education" with "other cultural matters.") Third, what, for that matter, is "education"? (Formal instruction only?) Fourth, is there a continuing obligation, subject to reassessment from time to time? Fifth, how far is the reasonableness of the compensation judicially reviewable? Finally, does section 40 create a statutory obligation enforceable by law?

G. Minimum and Maximum Time Period for the Operation of the "General" Procedure.

Section 39 reads as follows:

39. (1) A proclamation shall not be issued under subsection 38 (1) before the expiration of one year from the adoption of the resolution initiating the amendment procedure thereunder, unless the legislative assembly of each province has previously adopted a resolution of assent or dissent.

(2) A proclamation shall not be issued under subsection 38(1) after the expiration of three years from the adoption of the resolution initiating the amendment procedure thereunder.

In effect section 39(2) imposes a maximum time period of three years. (Quaere whether one of the federal or provincial houses can "re-initiate" an alreadypending proposal before the expiry of the three years.) On the other hand, section $39(1)$ is clearly designed to give each provincial assembly reasonable leisure to decide whether or not to dissent, and reasonable opportunity, if it so chooses, to dissent under section 38(3) before a proclamation is made under section 38(1)-for dissent is only possible, under section 38(3), "prior to the issue of the proclamation to which the amendment relates." Effectively, a minimum deliberative period of a year is available to each assembly in which it can act one way or the other. If so much as one province's assembly declines, or fails, to act either way, the amending process can be delayed for the full year. This may become serious in cases of urgency. Indeed, the power to delay, when others are anxious to move forward, can itself be used in bargaining. 


\section{H. Special Matters Reserved Exclusively to the "General" Procedure.}

"An amendment to the Constitution of Canada in relation to" a series of important matters can, under section 42(1), be made only under section 38(1). Under section 42(2), the power of dissent does not apply in such cases. Thus section 42(1) does not create a distinct amending procedure. It specifies cases where subsection 38(1) applies and excludes the application of subsections 38(2), (3) and (4). In a sense it creates a variant of the general procedure. It should be noted, however, that sections $46(1)$ and $47(1)$ do speak of section $42^{89}$ as creating a distinct procedure in its own right.

Although the effect of section $42(1)$ is essentially straightforward, it does give rise to some intricate problems, such as the meaning of the phrase "the territories" in section $42(1)(e)$. For example, if it were sought to extend all or some provinces' boundaries seaward, the proper application, respectively, of section 42(1)(e) and section 43 of the Constitution Act, 1982, and of section 3 of the Constitution Act, 1871,90 would pose difficult questions.

\section{VI \\ The "Unanimous Consent" Procedure}

Section 41 of the Constitution Act, 1982, reads as follows:

41. An amendment to the Constitution of Canada in relation to the following matters may be made by proclamation issued by the Governor General under the Great Seal of Canada only where authorized by resolutions of the Senate and House of Commons and of the legislative assembly of each province:

(a) the office of the Queen, the Governor General and the Lieutenant Governor of a province;

(b) the right of a province to a number of members in the House of Commons not less than the number of Senators by which the province is entitled to be represented at the time this Part comes into force;

(c) subject to section 43, the use of the English or the French language;

(d) the composition of the Supreme Court of Canada; and

(e) an amendment to this Part.

It should be noted that section 41 (e) imposes the requirement of using the "unanimous consent" procedure for any amendment to the provisions of Part V itself.

Although generally straightforward, section 41 seems bound to give rise to some important problems. First, the effect of section 41 (d) (along with that of section 42(1)(d)) on Parliament's legislative authority over the Supreme Court of

89. 42. (1) An amendment to the Constitution of Canada in relation to the following matters may be made only in accordance with subsection $38(1)$ :

(a) the principle of proportionate representation of the provinces in the House of Commons prescribed by the Constitution of Canada;

(b) the powers of the Senate and the method of selecting Senators;

(c) the number of members by which a province is entitled to be represented in the Senate and the residence qualifications of Senators;

(d) subject to paragraph 41 (d), the Supreme Court of Canada;

(e) the extension of existing provinces into the territories; and

(f) notwithstanding any other law or practice, the establishment of new provinces.

(2) Subsections 38 (2) to (4) do not apply in respect of amendments in relation to matters referred to in subsection (1).

90. See supra note $29 \&$ accompanying text. 
Canada has already been noted. ${ }^{91}$ Second, it is less than clear just how much of the law relating to the Crown is covered by section 41 (a): that is, what is meant by the "office" of the Sovereign and those of her representatives.

\section{VII}

\section{The "Special Arrangements" Procedure}

Section $43^{92}$ appears to be the Rubik's Cube of the Constitution Act, 1982, and in this instance no booklet is available to offer quick solutions. Although it was doubtless drafted as an independent procedure in its own right-and is referred to as such in sections $46(1)$ and $47(1)$ - it is possible to treat it as simply attaching a condition upon the exercise of section 38 , and requiring the consent of affected provinces in certain cases. So read, section 43 could arguably be said to serve the purpose of avoiding the anomaly which would seem to arise in some cases from the application of section 42. For example, an amalgamation of Nova Scotia, New Brunswick, and Prince Edward Island into a new province might otherwise be possible through section 38(1) (read with section 42(1)(d), which carries a non obstante clause), without these provinces being able to "dissent."93 Notwithstanding the appeal of reading section 43 to obviate such anomalies, it is probably, on balance, an independent amending procedure. If so, it is the least satisfactory of those enumerated in Part V.

It is a condition for the application of section 43 that the provision being subjected to amendment must be one "that applies to one or more but not all, provinces." However, it is neither necessary nor sufficient that the amendment itself will have such a restricted application. On the other hand, so long as one chooses, as the formal object of one's amendment, an existing constitutional provision-any existing provision-"that applies to one or more but not all provinces," there is nothing in the language of section 43 to require that the amendment itself be in any way germane to the subject matter of the provision being amended. Unless, therefore, the scope of section 43 is confined by judicial construction, the results could be perfectly bizarre. Almost any sort of special constitutional arrangement could be made with the concurrence of the federal authorities and those of the one or more provinces to which it would apply.

The language of section 43 also raises a more immediate question: By what legal means within the Constitution of Canada could Quebec be established as a sovereign independent state?

91. See text accompanying notes 44-52 supra.

92. 43. An amendment to the Constitution of Canada in relation to any provision that applies to one or more, but not all, provinces, including (a) any alteration to boundaries between provinces, and (b) any amendment to any provision that relates to the use of the English or the French language within a province, may be made by proclamation issued by the Governor General under the Great Seal of Canada only where so authorized by resolutions of the Senate and House of Commons and of the legislative assembly of each province to which the amendment applies.

Constitution Act, 1982, 1982 ch. 11 (U.K.), Sch. B.

93. See id. $\S 42(2)$. 


\section{VIII \\ The "Unilateral Federal" Procedure}

The Constitution Act, 1982, integrates directly into the scheme of Part V what may be called "unilateral federal" and "unilateral provincial" amending procedures. ${ }^{94}$ Section 44 of the 1982 Act provides: "Subject to sections 41 and 42, Parliament may exclusively make laws amending the Constitution of Canada in relation to the executive government of Canada or the Senate and House of Commons." Section 44 gives no power to alter the federal lawmaking process, as defined in the 1867 Act by section 17 and the opening words of section 91, through the subtraction of any of its elements. Nor does it appear to afford power to add further elements--be they other actors or other formalities-as conditions of valid legislation. Section 44 appears to allow unilateral federal statutory amendments to the existing individual elements of the federal parliament-the Crown, the Senate, and the House of Commons-whose continued existence section 44 presupposes; even this power is subject to severe restrictions..$^{95}$

The Canadian Bill of Rights ${ }^{96}$-which, it seems, is to be allowed to stand on the federal statute book-enumerates various fundamental rights and freedoms, and provides that:

. Every law of Canada shall, unless it is expressly declared by an Act of the Parliament of Canada that it shall operate notwithstanding the Canadian Bill of Rights, be so construed and applied as not to abrogate, abridge or infringe or to authorize the abrogation, abridgment or infringement of any of the rights or freedoms herein recognized and declared. ${ }^{97}$

94. The "unilateral federal" procedure of section 45 is the recognizable successor to section 91.1 of the amended 1867 Act (since 1949 the first item in the list of legislative powers of the Parliament of Canada):

The amendment from time to time of the Constitution of Canada, except as regards matters coming within the classes of subjects by this Act assigned exclusively to the Legislatures of the provinces, or as regards rights or privileges by this or any other Constitutional Act granted or secured to the Legislature or the Government of a province, or to any class of persons with respect to schools or as regards the use of the English or the French language or as regards the requirements that there shall be a session of the Parliament of Canada at least once each year, and that no House of Commons shall continue for more than five years from the day of the return of the Writs for choosing the House: Provided, however, that a House of Commons may in time of real or apprehended war, invasion or insurrection be continued by the Parliament of Canada if such continuation is not opposed by the votes of more than one-third of the members of such House.

British North America Act, 1867, 30 \& 31 Vict., ch. 3 (U.K.), $\$ 91.1$ (as amended by British North America (No. 2) Act, 1949, 12, 13 \& 14 Geo. 6, ch. 81 (U.K.)). This earlier provision has been repealed and replaced by Section 44 of the 1982 Act. The language of section 44 creating the unilateral federal procedure is framed in terms distinctly narrower than those of its predecessor, section 91.1 of the amended 1867 Act. However, in view of the highly restrictive construction placed upon the latter by the Supreme Court of Canada in the Senate Reference, the difference may not be very large in terms of actual legal results.

Reference re Legislative Authority of Parliament to Alter or Replace the Senate, 102 D.L.R.3d 1 (Can. 1979). The court held: (1) that section 91.1 of the 1867 Act did not enable the Parliament of Canada to abolish the Senate or alter its essential characteristics, id. at 18; (2) that "Canada" in section 91.1 referred to the "juristic federal unit" rather than to the country generally (thus rendering nugatory some enumerated exceptions to the section), id. at 12 ; and (3) that the federal parliamentary structure, at least in its essential respects, was also excepted by implication, id. at 13. In my view, the soundness of the Court's opinion is more than doubtful. For the most part, the difficulties created by the Senate Reference will disappear under the new constitutional regime.

95. See Constitution Act, 1982, 1982 ch. 11 (U.K.), Sch. B $\$ \$ 41-42$.

96. Act for the Recognition and Protection of Human Rights and Fundamental Freedoms, 8 \& 9 Eliz. 2, 1960 Can. STAT. ch. 44, Part I.

97. Id. $§ 2$. 
Only federal laws, of course, are affected, ${ }^{98}$ and in the absence of the required non obstante clause, a "law of Canada" which conflicts with the Canadian Bill of Rights is inoperative to that extent. ${ }^{99}$ In effect, the Canadian Bill of Rights has been read as a statute providing a guarantee that some or all provisions of any given federal Act, even though the bill has been duly passed by the Senate and Commons of Canada and assented to in the Queen's name, cannot operate as law without the additional formality of a non obstante clause. ${ }^{100}$

It is not easy to bring such a guarantee within the power conferred by section 44 of the Constitution Act, 1982. On the other hand, would the guarantee, if valid and in force before April 17, 1982, not continue until competently repealed? If such is the case, how could the guarantee competently be repealed?

IX

\section{The "Unilateral Provincial" Procedure}

The unilateral provincial procedure of section 45 of the 1982 Act is framed in terms much wider than those of section 44: "Subject to section 41, the legislature of each province may exclusively make laws amending the constitution of the province."101

The exclusion from the provincial amending power of the office of the Queen-even so far as it may be considered part of the provincial constitution-is, under the terms of section 41(a), no longer left to inference from the exclusion of the office of her representative, the Lieutenant Governor. Furthermore, in view of section 41 (c), a constitutional guarantee of language use $e^{102}$ can be treated as forming part of the relevant provincial constitution without involving the consequence that it is unilaterally amendable by the provincial legislature. It is no longer necessary to the entrenchment of the provision that it be held to be part of the general constitution of the country as opposed to part of the constitution of the province. ${ }^{103}$ That expedient may, however, be necessary to rationalize entrenchment of the new Charter as it concerns subjects of provincial jurisdiction.

98. Section 5(2) of the same Act provides:

The expression of "Law of Canada" in Part I means an Act of the Parliament of Canada enacted before or after the coming into force of this Act, any order, rule or regulation thereunder, and any law in force in Canada or in any part of Canada at the commencement of this Act that is subject to be repealed, abolished, or altered by the Parliament of Canada.

Act for the Recognition and Protection of Human Rights and Fundamental Freedoms, 8 \& 9 Eliz. 2, 1960 CAN. STAT. ch. $44, \S 5(2)$.

99. See Regina v. Drybones, 9 D.L.R.3d 473, 482 (Can. 1969).

100. Such a guarantee was, arguably, within federal legislative power under the terms of section 91.1 of the amended $1867 \mathrm{Act}$, though it is hard to see how this can be reconciled with the restrictive construction given to section 91.1 in the Senate Reference. See supra note 94, for discussion of Senale Reference.

101. The "unilateral provincial" procedure of section 45 is the recognizable successor to section 92.1 of the $1867 \mathrm{Act}$, although there are some points of difference:

92. in each Province the Legislature may exclusively make laws in relation to Matters coming within the Classes of Subjects next herein-after enumerated; that is to say,-

1. The Amendment from Time to Time, notwithstanding anything in this Act, of the

Constitution of the Province, except as regards the Office of Lieutenant Governor . . . .

102. See, e.g., Constitution Act, 1867, 30 \& 31 Vict., ch. 3 (U.K.), $\$ 133$.

103. See Attorney-Gen. of Quebec v. Blaikie, 101 D.L.R.3d 394, 401 (Can. 1979); Attorney-Gen. of Manitoba v. Forest, 101 D.L.R.3d 385, 388-89 (Can. 1979). 
Section 45 , in terms and by authority, ${ }^{104}$ confers a general power to deal with the constitution and organization of provincial institutions-legislative, executive, or other-subject to the position of the Sovereign and her representative, the Lieutenant Governor, protected by section 41 (a). Grammatically, at any rate, section 45 is wide enough to permit the provincial legislative institutions, however they may be lawfully constituted at any time, to reconstitute those very institutions with the utmost freedom. The old issue affecting its predecessor, section 92.1 that is, whether any implied limitations circumscribe that freedom-seems to continue. ${ }^{105}$ The question arises, for example, whether a referendum can lawfully be established as an altemative _or even as a substitute ${ }^{106}$ _-lawmaking authority alongside, or in place, of the provincial representative legislature, or whether the referendum can be imposed as a superadded condition necessary for the valid enactment of all legislation, or of legislation of some defined classes. ${ }^{107}$ Another such question is whether - so long as the law presently in force is carefully respected-additional houses can be added to the representative legislature or special majorities can be required in the legislative houses or, for that matter, in the referenda.

\section{$\mathrm{X}$ \\ Relationships Among Amending Procedures}

A principal question raised by Part $\mathrm{V}$ is how far the various procedures which it creates are mutually exclusive. Despite the appearance of the word "only" in section 43, and the word "exclusively" in sections 44 and 45 , these sections, it is submitted, ought not to be read so as to make them exclusive of section 38 . 1867).

104. Cf. Attorney-Gen. of Quebec v. Blaikie, 101 D.L.R.3d at 400 (construing $\$ 92.1$ of the Act of

105. The Constitution Act, 1982, 1982 ch. 11 (U.K.), Sch. B, through its section 53(1) and Schedule Item 17, effects the repeal of section 7(1) of the Statute of Westminster, 1931, 22 Geo. 5, ch. 4 (U.K.). This may affect the continuing applicability of section 5 of the Colonial Laws Validity Act, 1865, 28 \& 29 Vict., ch. 63 (U.K.), to the extent (if any) that the aforesaid section 7(1) had otherwise preserved its operation where amendments to the British North America Acts were concerned.

Section 5 of the Colonial Laws Validity Act, 1865, which in terms grants power to representative colonial legislatures to amend the colonial constitution in certain respects, was one of the constitutional bases for colonial legislation on "manner and form" of lawmaking. See infra note 107.

106. See In re Initiative and Referendum Act, 1919 A.C. 935 (P.C.), afforming Re Initiative and Referendum Act, 32 D.L.R. 148 (Man. 1916). There, the Privy Council, strictly speaking, left this question open. The Council construed the provincial referendum scheme (in my view, magis ut pereat quam valeat) as dispensing with the Lieutenant Governor's participation, and so struck the scheme down as violative of section 92.1 of the British North America Act, 1867, 30 \& 31 Vict., ch. 3 (U.K.).

The broader reasons of the Manitoba Court of Appeal in the decision below-taking a generally restrictive view of section 92.1 and apparently barring a referendum as a substituted legislative process, 32 D.L.R. at 153, have recently been cited (without express approval or disapproval) by the Supreme Court of Canada. Reference re Legislative Authority of Parliament to Alter or Replace the Senate, 102 D.L.R.3d 1, 14 (Can. 1979).

See generally Scott, Constituent Authority and the Canadian Provinces, 12 McGiLL L.J. 528 (1966-67).

107. See generally Attorney-General of New South Wales v. Trethowan, 1932 A.C. 526 (P.C.), afforming Attorney-General of New South Wales v. Trethowan, 44 C.L.R. 394 (Austl. 1931), afforming Trethowan v. Peden, 31 N.S.W. St. R. 183 (S. Ct. N.S.W. 1930).

The Privy Council's decision turned essentially on the Colonial Laws Validity Act, 1865, 28 \& 29 Vict., ch. 63 (U.K.), $\S 5$, and thus may be of marginal value in Canada today. See supra note 105. The decisions of the Australian courts, however, are based on much wider grounds. 
Mutual exclusivity inter se of the various procedures of Part $\mathrm{V}$, where it does not result from the very nature of the provision (as it does in the case of section 41 ), is of mischievous consequence, and should be avoided so far as possible.

It is important that, to the extent that the terms of two or more provisions overlap, they be read as concurrent pro tanto. In particular, as between more comprehensive provisions (such as section 38) and less comprehensive ones (such as section 43), it appears desirable that they be read whenever possible as standing in a hierarchy, so that the former stands to the latter as the "more difficult" to the "less difficult." Compliance with the former would be ipso facto compliance with the latter. Otherwise it may prove impossible to include, in a single proposed amendment and as a single package, a single provision having effects upon different parts of the constitution.

Both of the "unilateral" amending procedures, sections 44 and 45 , purport, in terms, to confer "exclusive" powers. But "exclusive" of what? That the powers conferred by sections 44 and 45 are, in principle, "exclusive" of one another is certain. It is no less certain that each of these two powers is, in principle, equally exclusive of all powers, however arising, belonging to the other level of government. Moreover, the powers of each province are, of course, exclusive of those of any other province.

In my view, however, sections 44 and 45 ought not to be held to be in any sense exclusive of the other amending procedures of Part V. It would be of mischievous consequence for an amendment, merely because it has an impact upon the federal executive government, or the Senate, or the House of Commons, to be invalid as an encroachment upon the "exclusive" powers of section 44, even though the amendment has duly complied with the requirements of another prima facie appropriate procedure - for example, section 38. (Indeed, section 41 requires the "unanimous consent" procedure to be employed; and section 42 requires the "general" procedure to be employed, for certain amendments dealing with federal institutions.)

Moreover, the internal provincial constitutions ought properly to be regarded as part of the "Constitution of Canada" as that term appears in Part V of the Constitution Act, 1982. ${ }^{108}$ If so, the various "bilateral" and "multilateral" procedures of Part $\mathrm{V}$ are not excluded from effecting amendments to matters contemplated by section 45 . This can be inferred from section $41(e)$, which allows section 45 itself to be amended by the "unanimous consent" procedure. The unanimous consent procedure can thus be used first to amend section 45 , and then to alter the provincial constitution. If so, it should be possible to compress the two stages into one, and to amend a provincial constitution directly through the use of section 41. ${ }^{109}$ While this is not of great practical consequence- since the concurrence of the provincial assembly is required in any event-it does point to the conclusions that provincial constitutions are part of the "Constitution of Canada," and that Part V procedures other than section 45-notably section 38-can be used to

108. See supra Pt. III.

109. McCawley v. The King, 1920 A.C. 691 (P.C.). 
amend them. Of course, the power of "dissent" furnished by section 38(3) would be available in such cases.

If Article $\mathrm{V}$ of the United States Constitution had come before a meeting of Canadian federal and provincial legal advisers, a provincial representative would immediately have insisted upon the addition, at the end of the Article, of something like the following words: "or of the application to such State of the benefit of this proviso." That, I think, explains a great deal about the way in which Part V of the Constitution Act, 1982, is drafted. Indeed, it shows, basically, how we in Canada write and read legislation. 
